\title{
Molecular profiles of the mouse postnatal development of the esophageal epithelium showing delayed growth start
}

\author{
HIROYUKI DAIKO ${ }^{1,2}$, NORIYUKI ISOHATA ${ }^{1,3}$, MASAYUKI SANO $^{1}$, KAZUHIKO AOYAGI $^{1}$, KENJI OGAWA $^{3}$, \\ SHINGO KAMEOKA ${ }^{2}$, TERUHIKO YOSHIDA ${ }^{1}$ and HIROKI SASAKI ${ }^{1}$ \\ ${ }^{1}$ Genetics Division, National Cancer Center Research Institute, Tsukiji 5-1-1, Chuo-ku, Tokyo 104-0045; \\ ${ }^{2}$ Department of Surgery II, School of Medicine, Tokyo Women's Medical University, 8-1, Kawadacho, \\ Shinjuku-ku, Tokyo 162-8666; and ${ }^{3}$ Medical Center East, School of Medicine, Tokyo Women's \\ Medical University, 1-10, Nishiogu 2-chome, Arakawa-ku, Tokyo 116-8567, Japan
}

Received July 24, 2006; Accepted September 18, 2006

\begin{abstract}
Studies on molecular mechanisms of self-renewal in normal stem cells are required for understanding the cancer stem cell. Self-renewal in many kinds of normal stem cells might be accelerated in the growth of a young organism and in the repair of damaged tissue. This study examined whether the esophagus in growing neonates provides an experimental system for studies on epithelial stem cell renewal. The esophageal epithelium consists of 3 layers, from the luminal side to the bottom: the differentiated, epibasal and basal cell layers. The basal cell layer is known to contain the stem cells for the esophageal epithelium. This basic architecture is observed both in mice and humans. We investigated the basal cells in the mouse neonate by immunostaining with a basal cell marker, nerve growth factor receptor (Ngfr), and compared the basal cell content in the esophageal epithelium between mice and humans. A mouse esophageal epithelial cell primary culture system was developed for studies on the basal cell growth and keratinocyte differentiation, and microarray analysis was conducted for obtaining expression profiles of the basal cells. It was revealed that the growth of the esophageal epithelium begins from postnatal day 3 , and that the timing is consistent with membrane localization of Ngfr in the basal cell. An increase in the basal cell number by Ngf treatment is observed in in vitro mouse esophageal epithelium cultures. Furthermore, mRNA overexpression of $P d g f r b$ encoding platelet derived growth factor receptor $B$ and $E g f r$ encoding epidermal growth factor receptor is associated with the timing of the growth of the esophageal epithelium in the neonatal mice. This study provides a new experimental model for studies on the growth
\end{abstract}

Correspondence to: Dr Hiroki Sasaki, Genetics Division, National Cancer Center Research Institute, 1-1, Tsukiji 5-chome, Chuo-ku, Tokyo 104-0045, Japan

E-mail: hksasaki@gan2.res.ncc.go.jp

Key words: esophagus, epithelium, nerve growth factor, microdissection, microarray of the basal cells, which are considered to include the stem cells, and on the enlargement of the body size in young organisms.

\section{Introduction}

There is increasing evidence supporting the cancer stem cell hypothesis (1-5). Normal stem cells in the adult organism are for tissue renewal, are immortal, and rather resistant to drugs. They are able to differentiate and form specific types of tissue by asymmetrically producing two daughter cells; a new stem cell, and a progenitor cell, which has differentiation and proliferation ability, but no capability for self-renewal. Cancer stem cells might be derived from self-renewing normal stem cells due to altered proliferative pathways or from progenitor cells that have acquired the ability of self-renewal. In both cases, dysregulation of stem cell self-renewal is a key event in tumorigenesis. Therefore, studies on the molecular mechanisms of self-renewal in normal stem cells are required for cancer stem cell research. Self-renewal in many kinds of normal stem cells might be accelerated in the growth of a young organism and in the repair of damaged tissue. But much remains to be learned on stem cell renewal in growing neonates. Furthermore, molecular biological study on the enlargement of the body size in young organisms has rarely been found.

The esophagus may be one of the most simple organs. The luminal surface of the human esophagus is linked by a nonkeratinizing, stratified squamous epithelium. Histologically, the esophageal epithelium can be divided into three layers: a single basal cell layer that adheres to the basement membrane (the basal cell layer), a variable number of small basophilic cell layers above this (the epibasal cell layers), and multiple layers of progressively flattened, differentiated squamous cells (the differentiated cell layers) $(6,7)$. Cell proliferation is limited to the basal layer and the epibasal layers, from which cells are thought to migrate towards the lumen side. In general, stem cells are thought to be not only self-renewing but also slowly or rarely cycling. However, most of the basal cells actively proliferate and are thus considered to be transit amplifying cells, and only a limited number of the basal cells 
Table I. PCR primer sequences.

\begin{tabular}{lll}
\hline Gene & \multicolumn{1}{c}{ Forward primers } & Reverse primers \\
\hline Krt14 & 5'-CCAATTCTCCTCATCCTCT-3' & 5'-TCTTCCAGCAGTATCTGCGT-3' \\
Krt15 & 5'-TGAGTTGCAGTCTCAGCTCA-3' & 5'-CCAATACCAGCCATCTTAGC-3' \\
Itga1 & 5'-AAGCAGACCTGCTGTTCATC-3' & 5'-CCATCTCTCCATGGATAGAC-3' \\
Itgb1 & 5'-TCGTGCATGTTGTGGAGACT-3' & 5'-GAGCTTGATTCCAATGGTCC-3' \\
Itgb4 & 5'-AGGGTATCATCACCATCGAG-3 & 5'-TTATGGTTCCTGGACAGCAC-3' \\
Ngfr & 5'-ATTGCTCCATCTTGGCTGCT-3' & 5'-ATTGAGCAGCTTCTCGACCT-3' \\
Pdgfrb & 5'-ATGAGAGGAAGATGCTGACG-3' & 5'-GTAGGACTCGAGATAACCCA-3' \\
Egfr & 5'-GAACATCACCTGTACAGGCA-3' & 5'-TCTGGGTACGTTCAATGGCA-3' \\
Robo1 & 5'-GCTCTGTGACTGTAGGTTTC-3' & 5'-GCTAATTTGAAGAAGCCCCA-3' \\
Actin & 5'-CTACAAATGTGGCTGAGGAC-3 & 5'-CACAGAAGCAATGCTGTCAC-3' \\
\hline
\end{tabular}

are stem cells. Thus, esophageal epithelial cell differentiation follows a unidirectional linear pathway from the stem cells to the transient amplifying cells in the basal cell layer, and thence to the epibasal cells, and finally to the differentiated cell.

During the process of establishing a mouse esophageal epithelial cell culture system, we discovered that esophageal epithelium growth begins from postnatal day 3 , and that the timing is consistent with membrane localization of nerve growth factor receptor Ngfr and mRNA overexpression of $P d g f r b$ (platelet derived growth factor receptor ß) and Egfr (epidermal growth factor receptor) in the basal cells. The basal cell number was increased by Ngf treatment in in vitro mouse epithelium cultures. This study provides a new experimental model for studies on the growth of the basal cells, which include esophageal epithelial stem cells and on the enlargement of the body size in young organisms.

\section{Materials and methods}

Immunohistochemistry. For immunohistochemical staining of frozen sections of murine esophagus, specimens that were embedded in a TissueTek OCT medium (VWR Scientific, Torrance, CA) and stocked at $-80^{\circ} \mathrm{C}$ until use were cut into $5-\mu \mathrm{m}$ sections, which were then immediately fixed in $100 \%$ ethanol for 2 min. Blocking was carried out with the Vector M.O.M. kit (for antibody made in mouse, BMK-2202; Vector Laboratories, Burlingame, CA), and the Dako protein block (for others, X0909; Dako, Carpinteria, CA) for $30 \mathrm{~min}$ at room temperature. Sections were incubated overnight at $4^{\circ} \mathrm{C}$ with diluted rabbit polyclonal antibody directed against mouse Ngfr (ab8875, 1:50; Abcam, Cambridge, MA), and rat monoclonal antibody directed against Integrin b1 (Itgb1) (558741, 1:50; BD Biosciences, San Jose, CA). On the following day, after washing sections with PBS containing $0.1 \%$ Tween-20, endogenous peroxidase activity was blocked with $3 \% \quad \mathrm{H}_{2} \mathrm{O}_{2}$ in methanol for $30 \mathrm{~min}$. Biotinylated secondary antibodies were applied for $30 \mathrm{~min}$ at room temperature. Detection was carried out with the Vectastain ABC Elite kit (PK-6100; Vector Laboratories). After extensive rinsing and incubation with an avidin-biotin immunoperoxidase complex, staining was visualized with the DAB system (Nichirei, Tokyo, Japan), and the sections were counter-stained with Mayer's hematoxylin.
The primary culture of mouse esophageal epithelial cells. On early postnatal days $1-7$, the esophagi of the $57 \mathrm{BL} / 6 \mathrm{~J}$ mice were minced, then suspended and sterilized with $10 \%$ antibiotic-antimycotic (Invitrogen, Carlsbad, CA), and digested by incubation for $12 \mathrm{~min}$ at $37^{\circ} \mathrm{C}$ in $0.05 \%$ collagenase1 (Nitta Gelatine, Osaka, Japan), and then manually dissociated with scissors, and incubated for $5 \mathrm{~min}$ at $37^{\circ} \mathrm{C}$ with a $1: 1$ ratio of $0.5 \%$ Trypsin-EDTA (Invitrogen) and Dispase 10000PU (Godo Shusei, Tokyo, Japan) in PBS (-). Following filtration with a $100-\mu \mathrm{m}$ cell strainer (Falcon, Franklin Lakes, NJ), the digested tissue fragments were centrifuged for 5 min at 1,200 rpm, resuspended in Defined Keratinocyte-SFM (Invitrogen) with $1 \mathrm{ml}$ of supplement and antibiotic-antimycotic, plated in type 1 collagen-coated 35-mm culture dishes (Iwaki, Tokyo, Japan) and incubated at $37^{\circ} \mathrm{C}$ in a humidified atmosphere flushed with $5 \% \mathrm{CO}_{2}$ in the air. Twenty-four hours after plating, nonadhesive cells were discarded. The culture medium was changed every other day. For Ngf treatment, $2 \mu \mathrm{g} / \mathrm{ml}$ of recombinant mouse Ngf (13257-019; Invitrogen) was added.

Immunostaining of mouse primary cultured cells. Cultured cells were fixed in $4 \%$ paraformaldehyde for $20 \mathrm{~min}$ and permeabilized in $0.3 \%$ TritonX-100 for $10 \mathrm{~min}$ at room temperature. Blocking was carried out with the Vector M.O.M. kit for $60 \mathrm{~min}$. The dishes were incubated overnight at $4{ }^{\circ} \mathrm{C}$ with diluted rabbit polyclonal antibody directed against mouse $\mathrm{Ngfr}$ (ab8875, 1:50; Abcam). On the following day, endogenous peroxidase was blocked with $3 \% \mathrm{H}_{2} \mathrm{O}_{2}$ in methanol for $30 \mathrm{~min}$. Biotinylated secondary antibodies were applied for $30 \mathrm{~min}$ at room temperature. Detection was carried out by using a Vectastain ABC Elite kit (Vector Laboratories) and the DAB system (Nichirei), as previously described.

Isolation of the basal cell from mouse primary cultured cells by magnetic cell sorting (MACS). MACS was carried out according to the manufacturer's protocol (Miltenyi Biotec $\mathrm{GmbH}$, Germany). In brief, mouse primary cultured cells were tripsinized, centrifuged for $5 \mathrm{~min}$ at $1200 \mathrm{rpm}$, and then blocked with $0.5 \%$ BSA. The cells were incubated with monoclonal anti-mouse integrin b1 (CD29) antibody (diluted $1: 50$ in $0.5 \% \mathrm{BSA}$; BD Biosciences) for $30 \mathrm{~min}$ at $4^{\circ} \mathrm{C}$. After washing twice with $0.5 \% \mathrm{BSA}$, the cells were labeled with 
anti-rat IgG antibody-microbeads (1:5; Miltenyi) for $15 \mathrm{~min}$ at $4^{\circ} \mathrm{C}$. Using the auto MACS system (Miltenyi), CD29positive and -negative cells were recovered.

Laser-captured microdissection (LCM) and RNA preparation for RT-PCR. Mouse esophagus was embedded in TissueTek OCT medium (VWR Science) and snap-frozen in liquid nitrogen. The cryostat sections $(8-\mu \mathrm{m})$ were lasermicrodissected with a Pixcell II LCM system (Arcturus Engineering, Mountain View, CA).

Microarray analysis. Total RNA was isolated by suspending the cells in an Isogen lysis buffer (Nippon Gene, Toyama, Japan) followed by precipitation with isopropanol. The mRNA was amplified by an efficient method of high-fidelity mRNA amplification developed in our laboratory, called TALPAT (T7RNA polymerase promoter-attached, adaptor ligationmediated, and PCR amplification followed by in vitro T7transcription) (8). We used Mouse Expression Array 430A (Affymetrix, Santa Clara, CA) for analysis of mRNA expression levels corresponding to 22,690 transcripts. The procedures were conducted according to the supplier's protocols. Briefly, $10 \mu \mathrm{g}$ of fragmented cRNA was hybridized to the microarrays in $200 \mu \mathrm{l}$ of a hybridization cocktail at $45^{\circ} \mathrm{C}$ for $16 \mathrm{~h}$ in a rotisserie oven set at $60 \mathrm{rpm}$. The arrays were then washed with a nonstringent wash buffer (6X SSPE) at $25^{\circ} \mathrm{C}$, followed by a stringent wash buffer [100 mM MES (pH 6.7), $0.1 \mathrm{M} \mathrm{NaCl}$, and $0.01 \%$ Tween-20] at $50^{\circ} \mathrm{C}$, stained with streptavidin phycoerythrin (Invitrogen), washed again with 6X SSPE, stained with biotinylated anti-streptavidin IgG, followed by a second staining with streptavidin phycoerythrin and a third wash with 6X SSPE. The arrays were scanned using a GeneArray scanner (Affymetrix) at $3-\mu \mathrm{m}$ resolution, and the expression value (average difference; AD) of each gene was calculated using GeneChip Analysis Suite version 4.0 software (Affymetrix). The mean of $\mathrm{AD}$ values in each experiment was 1000 to reliably compare variable multiple arrays. More than 2-fold overexpressed genes were selected by Microsoft Excel.

Reverse transcription-polymerase chain reaction ( $R T-P C R)$. Total RNA was isolated by suspending the cells in an Isogen lysis buffer (Nippon Gene) followed by precipitation with isopropanol. The mRNA was amplified by TALPAT. RT-PCR was carried out using primer sets designed for detecting the 3' side of cDNA of each gene. Primer sequences are shown in Table I. PCR was performed under conditions of 30-35 cycles of 3 steps of temperature, $95^{\circ} \mathrm{C}$ for $1 \mathrm{~min}, 55^{\circ} \mathrm{C}$ for $1 \mathrm{~min}$, and $72^{\circ} \mathrm{C}$ for $1 \mathrm{~min}$, using the AccuPrime Taq DNA polymerase system (Invitrogen).

\section{Results}

The growth of the esophageal epithelium in mouse neonate. In humans $(6,7)$, the lamina propria invaginates the epithelium, producing papillary structures. Hence, the basal layer is further divided into two types: one flat (the interpapillary basal layer, IBL) and one covering the papillae (the papillary basal layer, PBL) (Fig. 1). It has been reported that esophageal stem cells, displaying asymmetrical mitotic figures, may be localized to the IBL while transit amplifying cells may reside in the PBL
$(6,7)$. In contrast to humans, the mouse esophageal epithelium is progressively keratinized towards the luminal surface and consists of very thin layers of the epibasal cell. Furthermore, the mouse esophageal epithelium shows at most a quite short papillary structure. Therefore, the interpapillary basal cells, which contain the stem cells, may be present in relatively large numbers in the esophageal epithelium of mice as compared with humans. This characteristic may provide an advantage in the establishment of a primary culture system for studies on the cell differentiation processes from the stem cells to the terminally differentiated squamous cells.

While establishing a mouse esophageal epithelial cell culture system, we investigated the growth of the esophagus in the mouse neonates. To calculate the number of the basal cell, we stained Ngfr because the basal cell expressed Ngfr in adult mice as well as in adult humans (9) (Figs. 1 and 2A). Unexpectedly, in the mouse neonate, Ngfr was detected in the lamina propria (Fig. 2A, red arrows) but not in the basal cell (black arrows) 0 to 2 days after birth, although Ngfr then became detectable in the basal cells on days 3 to 9 after birth (Fig. 2A). We further investigated Ngfr mRNA expression in the basal cells of postnatal day 1 mice. In the esophagus, the basal cell is known to express integrins including Integrin-b1 (Itgb1), -a1 (Itga1), and -b4 (Itgb4) as well as Ngfr (10). Hence, we isolated the basal cells from mouse esophageal epithelium primary cultures by MACS with anti-Integrin-b1 (CD29) antibody. Ngfr mRNA was shown to be enriched together with mRNAs of the above Integrins by RT-PCR in a CD29-positive cell fraction (Fig. 2B). These results suggest that $N g f r$ mRNA is expressed in the basal cells on early postnatal days (0-2 days). Therefore, on such days, Ngfr protein may have been secreted by the basal cell, with the result that this protein was accumulated and detected in the lamina propria (Fig. 2A). This notion is supported by a previous report showing that the truncated and secreted form is produced from a post-translational modification of the intact, surface-bound form of the Ngfr protein (11).

Next, in three sections of the esophagus of the three young and adult $57 \mathrm{BL} / 6 \mathrm{~J}$ mice, we counted the number of basal cells as an indicator of esophageal epithelium growth. The number of basal cells was approximately 200 per horizontal section until 2 days after birth; 250 on postnatal day 3; 400 on day 9 , and 600 in adult mice (Fig. 3A). Considering the circadian control of cell division, we investigated the expression of proliferating cell nuclear antigen (Pcna) in the esophagi of the neonates at the same time in the morning. As shown in Fig. 3B, a majority of Pcna-positive cells were basal cells. Consistent with the increase of the basal cells from postnatal day 3 (Fig. 3A), the rate of the Pcna-positive basal cells in postnatal day 3 mice significantly increased compared with that in the day 2 mice (Fig. 3B). These results suggest that the growth of the esophageal epithelium begins from postnatal day 3, and that the timing is consistent with that when $\mathrm{Ngfr}$ localizes to the basal cell membrane.

Increase of the basal cell number by Ngf treatment in in vitro mouse esophageal epithelium cultures. By the procedures described in the Materials and methods section, we first tried to culture mouse esophageal epithelium of the $57 \mathrm{BL} / 6 \mathrm{~J}$ mice on postnatal days 1 to 14 and at the adult stage (data not 


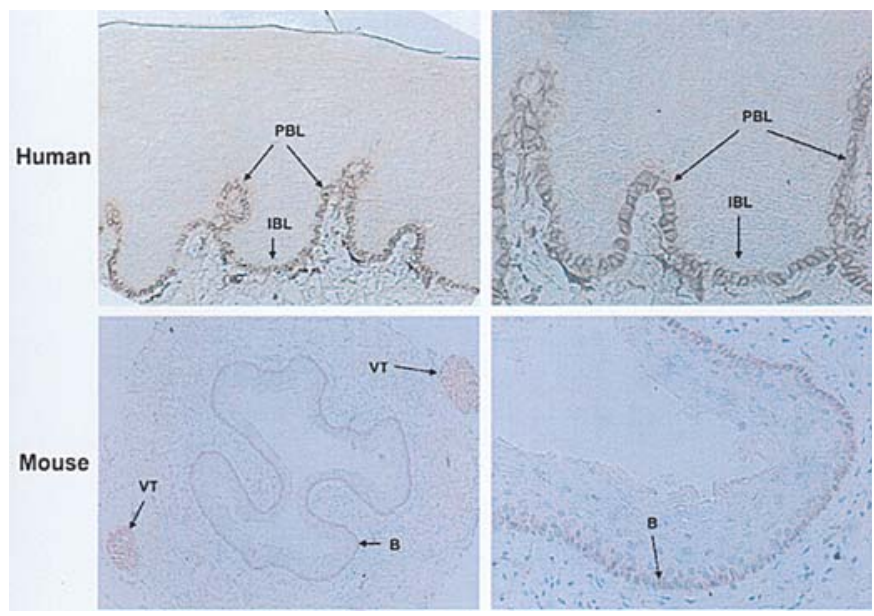

Figure 1. Expression of NGFR/Ngfr in the esophageal epithelium in adult humans and mice. Immunohistochemical analyses for NGFR/Ngfr shows that this receptor is localized in the basal cell membrane in adult humans (upper) and adult mice (lower). For tissues other than the epithelium, only the vagus nerve trunk expresses this receptor. BL, papillary basal cell; IBL, interpapillary basal cell; B, basal cell; VT, vagus nerve trunk. Left, magnification $\mathrm{x} 100$; right, magnification $\mathrm{x} 200$.

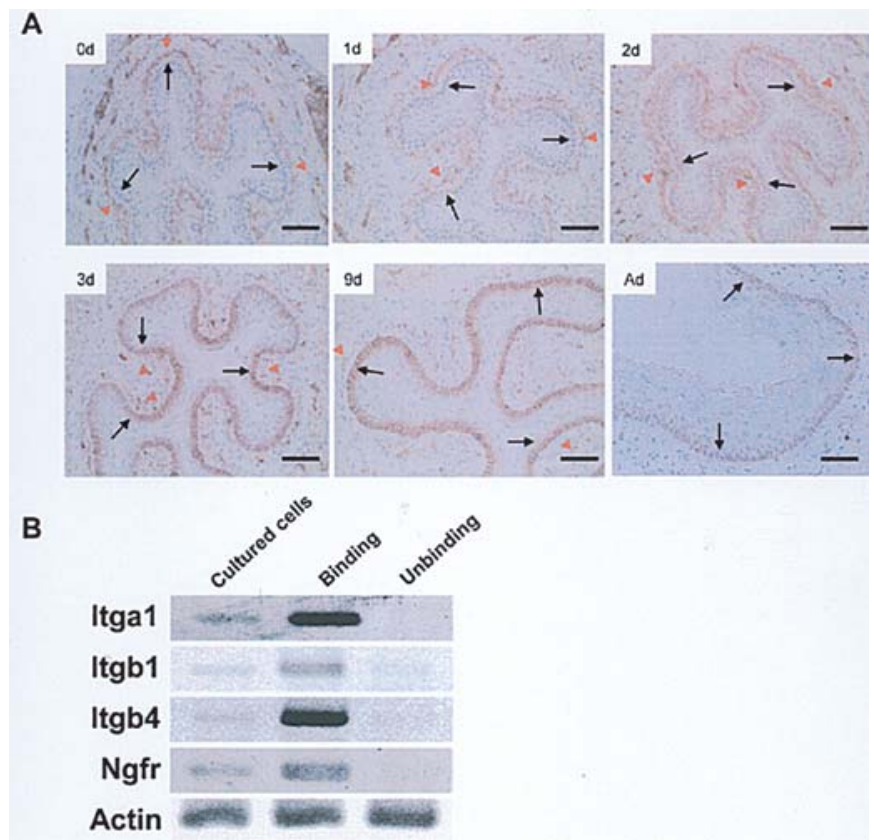

Figure 2. Expression of Ngfr protein and Ngfr mRNA in the basal cells in the neonatal mice. (A) Immunostaining of Ngfr in young mice (magnification $\mathrm{x} 100$ ). In mouse neonate, $\mathrm{Ngfr}$ was detected in the lamina propria (red arrows) but not in the basal cell (black arrows) 0 to 2 days after birth, while $\mathrm{Ngfr}$ was detected in the basal cell on days 3 to 9 after birth. 0d-9d, the postnatal 0-9 day mice; Ad, adult mice. Bar, $200 \mu \mathrm{m}$. (B) $N g f r$ mRNA expression in the basal cells of postnatal day 1 mice. In the esophagus, the basal cell is known to express Integrins including Integrin-b1 (Itgb1), -a1 (Itga1), and -b4 (Itgb4) as well as Ngfr. The basal cells from the esophageal epithelium primary cultures of postnatal day 1 mice are isolated by MACS with anti-Integrin b1 (CD29) antibody, and then RT-PCR is performed. Ngfr mRNA is enriched together with mRNAs of the above Integrins in a CD29positive cell fraction. Binding, CD29-positive fraction; Unbinding, CD29negative fraction.

shown). The cells were found to grow very well and form large colonies after 14 days in the culture of the esophageal
A

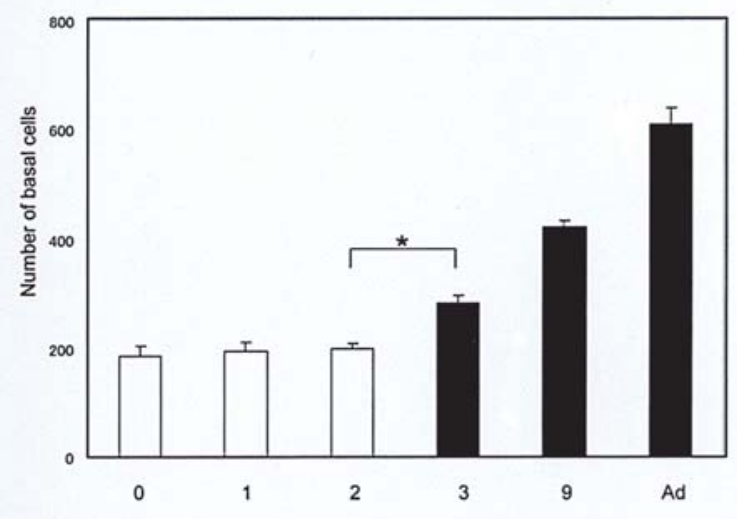

B

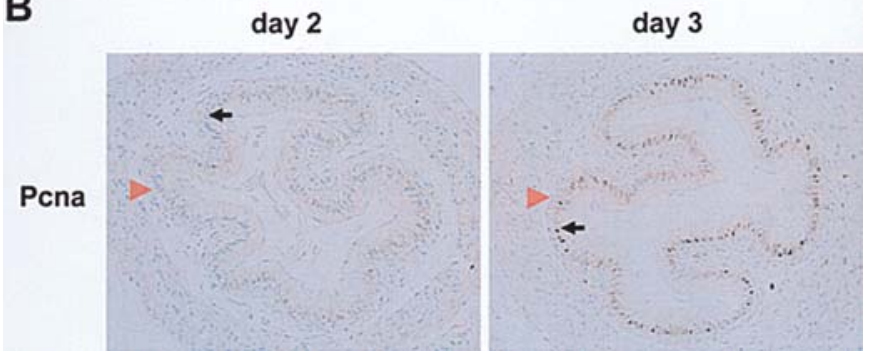

Figure 3. The growth of the esophageal epithelium in the mouse neonate. (A) The number of basal cells per horizontal section was counted for each postnatal day designated in abscissa. ${ }^{*}$ Increase in the number of the basal cells on postnatal day 3 is statistically significant at $\mathrm{P}<0.05$ as compared to that on postnatal day 2. (B) The rate of Pcna-positive basal and epibasal cells on postnatal day 2 mice significantly increased compared with that on day 3 mice (magnification x100). Black arrow, the basal cells; red arrow, the lamina propria.

epithelial cells isolated from the early postnatal days 1 to 7 ; however, in the culture derived from the postnatal day 8 to 14 epithelia, the cells decreased growth and formed small colonies. Furthermore, in the adult mice, the esophageal epithelial cells did not even form small colonies. Next, we characterized the primary cultures of the esophageal epithelium on early postnatal day 3 for 14 days (Fig. 4B). On day 1 after culture, a single cell was dominantly present (red arrowhead), and on days 2 to 4 , the majority of colonies formed were small, composed of $<10$ cells that gave only a positive staining for a basal cell marker, cytokeratin 14 (Krt14) (7) (Fig. 4A and B). However, approximately half of the colonies became large, comprising 20-30 cells on days 5 to 6 . The majority of the outer cells of the colonies gave a positive staining for Krt14, while that of the inner cells was positive for a differentiated cell marker, Krt10 (12,13) (Fig. 4A and B). Furthermore, on days 7 to 14 , keratinized cells appeared in the inner layers of most of the colonies.

In this primary culture system of neonatal murine esophageal epithelial cells, the most important characteristics are that colonies containing Krt14-positive undifferentiated cells (basal cells) and Krt10-positive differentiated cells seem to be produced from a single basal cell, and that, until day 4 after culture, only the basal cell population increases in each colony. As described in the introduction, only the stem cells, which may be present in the basal cell layer, have the ability of selfrenewal and asymmetric growth, while the progenitor cells (transit amplifying cells), which constitute most of the basal 
A
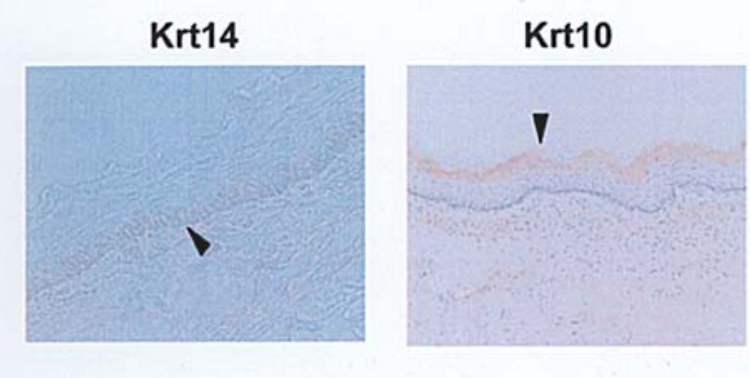

C

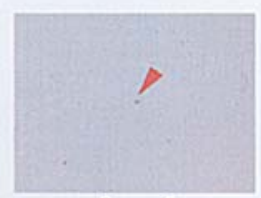

day 1

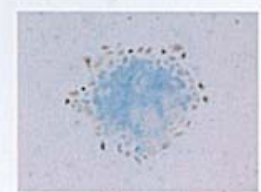

day 7

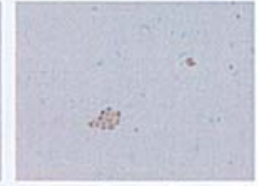

day 4

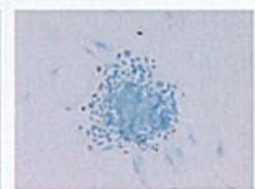

day 8

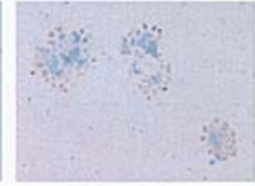

day 6

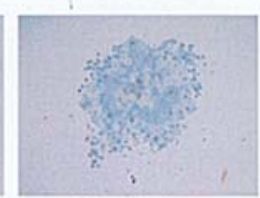

day 14
B

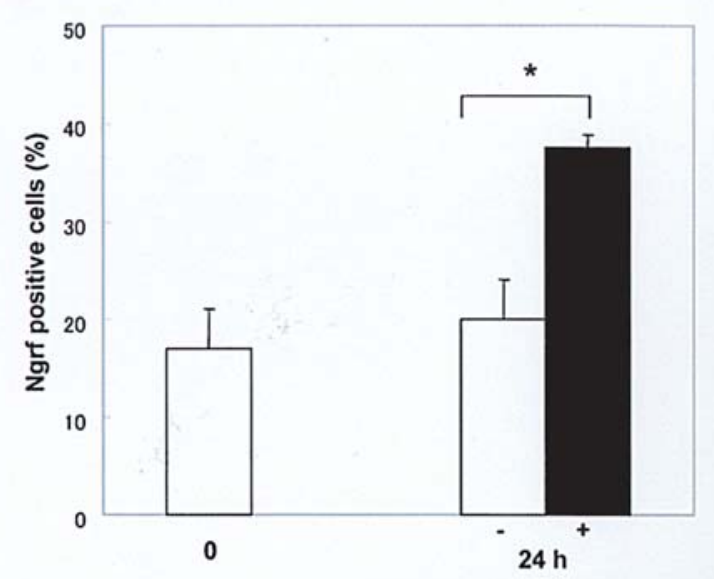

D

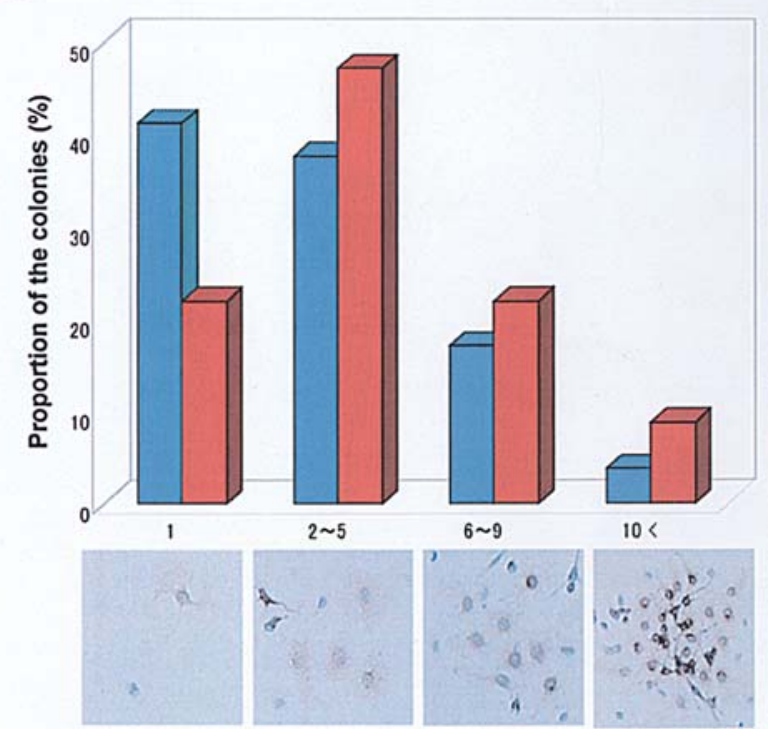

Figure 4. Characterization of the mouse primary esophageal epithelial cell culture. (A) Immunostaining of the differentiated and basal cell markers in the mouse esophageal epithelium (magnification x100). Cytokeratin 14 (Krt14) is stained in the basal cells, while Cytokeratin 10 (Krt10) is stained in the differentiated cells. (B) Immunostaining of Krt14 and Krt10 in the mouse primary esophageal epithelial cell culture (magnification x100). On day 1 after culture, most cells are present as a single isolated cell (red arrow). On early days (days 1-4), most cells in a small colony were positive for a basal cell marker, Krt14 (brown). On days 6 to 14, each colony became larger, and the majority of the 'outer' cells on the periphery of the colonies showed a positive staining for Krt14 (Brown), while the 'inner' cells in the central portion of the colonies showed a positive staining for a differentiated cell marker, Krt10 (Blue). Furthermore, keratinized cells appeared in the inner layers of most of the colonies. (C) The recombinant mouse Ngf was added to the primary cultures of the postnatal day 3 mice. *After $24 \mathrm{~h}$, the number of Krt14-expressing cells in the Ngf-treated cultures significantly increased at P $<0.05$ compared with that in the untreated control. (D) The colonies enlarged after Ngf-treatment. Red, Ngf-treated; blue, untreated. Representative colonies (magnification x200) containing various numbers of Ngfr-positive cells are shown (lower): 1, one cell; 2-5, 2-5 cells; 6-9, 6-9 cells; >10, more than 10 cells, respectively.

cells, have no capacity for self-renewal. The characteristics of the primary cultures suggest that a symmetrical cell division, resulting in two daughters of the basal cells, preferentially occurred from day 1 to 4 after culture. From day 5 to 14 , an asymmetrical cell division seems to occur preferentially, producing one basal and one differentiated cell, possibly through the epibasal daughter cell. Therefore, this esophageal epithelial cell culture system of the neonatal mice is useful for studies on the basal cell self-renewal and keratinocyte differentiation.

To examine the effect of Ngf in the basal cells, we added recombinant mouse Ngf to the primary cultures of the postnatal day 3 mice. After $24 \mathrm{~h}$, the number of cells expressing Krt14 increased compared with that of the untreated control (Fig. 4C). Next, we stained another basal cell marker, Ngfr, and investigated the colony size. The colonies consisting of the Ngfr-positive cell were also observed to enlarge after Ngf-treatment for $24 \mathrm{~h}$ (Fig. 4D). These results suggest that $\mathrm{Ngf}$ may be required for basal cell growth and/or survival with the membrane localization of its receptor.

Expression change of other receptor genes in the basal cell during growth. To identify genes up-regulated in the basal cells after postnatal day 3 , we performed microarray analysis of the primary cultured esophageal epithelial cells of postnatal day 4 and day 1 mice. Of 22,690 genes, 274 genes were identified as more than 2-fold up-regulated in the cultured cells of the postnatal day 4 mice (Table II). We found three genes, roundabout homolog 1 (Robol), Egfr and Pdgfrb, as the gene encoding growth factor receptor, which were highly 
Table II. Gene candidates whose expression is up-regulated in the esophageal basal cells after postnatal day 3 .

No. Entrez Gene symbol Signal intensity Fold change gene ID $\overline{\text { day } 1^{\mathrm{a}} \text { day } 4^{\mathrm{b}}}$ day 4/day

\begin{tabular}{|c|c|c|c|c|c|}
\hline 1 & 12826 & Col4a1 & $1^{\mathrm{c}}$ & 2985 & 2984.6 \\
\hline 2 & 22139 & $\operatorname{Ttr}$ & 1 & 2207 & 2207.2 \\
\hline 3 & 20760 & Sprr2f & 1 & 2017 & 2016.8 \\
\hline 4 & 66060 & 0610010O12Rik & 1 & 1315 & 1315.2 \\
\hline 5 & 19296 & Pvt1 & 1 & 1296 & 1296.4 \\
\hline 6 & 80837 & Rhoj & 1 & 1272 & 1271.7 \\
\hline 7 & 20815 & Srpk1 & 1 & 1257 & 1257.4 \\
\hline 8 & 17075 & Tacstd 1 & 1 & 1228 & 1228.0 \\
\hline 9 & 20305 & Ccl6 & 1 & 1200 & 1199.5 \\
\hline 10 & 66434 & 2010003O02Rik & 1 & 1119 & 1118.6 \\
\hline 11 & 22643 & Zfp101 & 1 & 1083 & 1082.9 \\
\hline 12 & 235674 & MGC29978 & 1 & 1032 & 1031.5 \\
\hline 13 & 12925 & Crip1 & 1 & 1000 & 999.7 \\
\hline 14 & 85031 & Pla1a & 1 & 990 & 989.9 \\
\hline 15 & 225283 & ВC021395 & 1 & 981 & 981.4 \\
\hline 16 & 18830 & Pltp & 1 & 954 & 953.8 \\
\hline 17 & 83675 & Bicc1 & 1 & 952 & 951.7 \\
\hline 18 & 12642 & $\mathrm{Ch} 25 \mathrm{~h}$ & 1 & 939 & 938.5 \\
\hline 19 & 66128 & Mrps36 & 1 & 877 & 877.1 \\
\hline 20 & 66601 & 2010002A20Rik & 1 & 845 & 845.4 \\
\hline 21 & 21804 & Tgfb1i1 & 1 & 836 & 836.3 \\
\hline 22 & 19335 & Rab23 & 1 & 812 & 811.6 \\
\hline 23 & 52123 & Agpat5 & 1 & 805 & 805.1 \\
\hline 24 & 14205 & Figf & 1 & 800 & 800.4 \\
\hline 25 & 20842 & Stag1 & 1 & 770 & 769.6 \\
\hline 26 & 52535 & D14Ertd209e & 1 & 761 & 761.1 \\
\hline 27 & 52357 & D8Ertd594e & 1 & 748 & 747.9 \\
\hline 28 & 69875 & Ndufa11 & 1 & 746 & 746.2 \\
\hline 29 & 72415 & Sgol1 & 1 & 744 & 744.0 \\
\hline 30 & 21894 & $\mathrm{~T} \ln 1$ & 1 & 733 & 732.7 \\
\hline 31 & 16782 & Lamc2 & 1 & 729 & 729.4 \\
\hline 32 & 94227 & Pi15 & 1 & 728 & 727.6 \\
\hline 33 & 109225 & Ms4a7 & 1 & 723 & 722.5 \\
\hline 34 & 20758 & Sprr2d & 1 & 703 & 702.7 \\
\hline 35 & 56043 & Akrle1 & 1 & 691 & 690.6 \\
\hline 36 & 52443 & Mrpl48 & 1 & 690 & 690.1 \\
\hline 37 & 73826 & Poldip3 & 1 & 690 & 689.6 \\
\hline 38 & 15547 & Htf9c & 1 & 666 & 665.8 \\
\hline 39 & 13436 & Dnmt3b & 1 & 655 & 654.7 \\
\hline 40 & 21930 & Tnfaip6 & 1 & 653 & 653.3 \\
\hline 41 & 57814 & Kcne4 & 1 & 653 & 652.5 \\
\hline 42 & 227743 & Mapkap1 & 1 & 639 & 638.8 \\
\hline 43 & 74325 & Cltb & 1 & 638 & 637.7 \\
\hline 44 & 11350 & Abl1 & 1 & 637 & 636.8 \\
\hline 45 & 12868 & Cox8a & 1 & 636 & 635.6 \\
\hline 46 & 26949 & Vat1 & 1 & 636 & 635.6 \\
\hline 47 & 64929 & Scel & 1 & 616 & 616.4 \\
\hline 48 & 228911 & Sdccag331 & 1 & 614 & 614.2 \\
\hline 49 & 53421 & Sec61a1 & 1 & 614 & 614.2 \\
\hline 50 & 68936 & 1190017O12Rik & 1 & 599 & 598.5 \\
\hline 51 & 67198 & 2810022L02Rik & 1 & 598 & 597.6 \\
\hline 52 & 68494 & 1110011C06Rik & 1 & 593 & 592.7 \\
\hline 53 & 11857 & Arhgdib & 1 & 591 & 590.6 \\
\hline 54 & 494448 & Cbx6 & 1 & 574 & 574.0 \\
\hline 55 & 14221 & Fjx1 & 1 & 574 & 573.7 \\
\hline
\end{tabular}

Table II. Continued.

No. Entrez Gene symbol Signal intensity Fold change

\begin{tabular}{|c|c|c|c|c|c|}
\hline \multirow{2}{*}{\multicolumn{3}{|c|}{ gene ID }} & \multirow{3}{*}{$\frac{d \text { day } 1^{\mathrm{a}}}{1}$} & \multirow{3}{*}{$\frac{\operatorname{day} 4^{b}}{566}$} & \multirow{3}{*}{$\frac{\text { day } 4 / \text { day } 1}{565.8}$} \\
\hline & & & & & \\
\hline 56 & 15374 & Hn1 & & & \\
\hline 57 & 12870 & $\mathrm{Cp}$ & 1 & 564 & 563.5 \\
\hline 58 & 12798 & Cnn2 & 1 & 562 & 561.7 \\
\hline 59 & 12550 & Cdh1 & 1 & 554 & 553.9 \\
\hline 60 & 54138 & Sca10 & 1 & 552 & 551.5 \\
\hline 61 & 11544 & Adprh & 1 & 548 & 547.5 \\
\hline 62 & 17533 & Mrc1 & 1 & 547 & 547.4 \\
\hline 63 & 66448 & $\operatorname{Mrpl} 20$ & 1 & 540 & 540.3 \\
\hline 64 & 21346 & Tagln 2 & 1 & 540 & 539.8 \\
\hline 65 & 74100 & MGI:107562 & 1 & 537 & 536.9 \\
\hline 66 & 67726 & 1810073G14Rik & 1 & 532 & 531.5 \\
\hline 67 & 26939 & Polr3e & 1 & 530 & 530.4 \\
\hline 68 & 16956 & Lpl & 1 & 530 & 529.8 \\
\hline 69 & 104806 & Fancm & 1 & 529 & 529.1 \\
\hline 70 & 24030 & Mrps12 & 1 & 529 & 529.1 \\
\hline 71 & 102209 & Snapc2 & 1 & 528 & 528.2 \\
\hline 72 & 59042 & Cope & 1 & 525 & 524.9 \\
\hline 73 & 16688 & Krt2-6b & 1 & 525 & 524.5 \\
\hline 74 & 30794 & Pdlim4 & 1 & 521 & 521.2 \\
\hline 75 & 72388 & Ripk4 & 1 & 511 & 510.9 \\
\hline 76 & 68611 & Mrpl28 & 1 & 509 & 508.5 \\
\hline 77 & 217684 & 4933426M11Rik & 1 & 506 & 505.5 \\
\hline 78 & 105837 & Mtbp & 1 & 503 & 503.2 \\
\hline 79 & 66208 & Nenf & 1 & 501 & 501.4 \\
\hline 80 & 16687 & Krt2-6a & 164 & 4166 & 25.4 \\
\hline 81 & 109620 & Dsp & 148 & 1953 & 13.2 \\
\hline 82 & 217258 & Abca8a & 760 & 8330 & 11.0 \\
\hline 83 & 11668 & Aldh1a1 & 539 & 5578 & 10.3 \\
\hline 84 & 17313 & Mgp & 3382 & 23271 & 6.9 \\
\hline 85 & 66695 & Aspn & 505 & 3088 & 6.1 \\
\hline 86 & 20210 & Saa3 & 3060 & 17697 & 5.8 \\
\hline 87 & 116903 & Calcb & 237 & 1365 & 5.8 \\
\hline 88 & 22061 & Trp63 & 117 & 635 & 5.4 \\
\hline 89 & 68659 & 1110032E23Rik & 640 & 3302 & 5.2 \\
\hline 90 & 23794 & Adamts5 & 604 & 3066 & 5.1 \\
\hline 91 & 66607 & Ms4a4d & 1266 & 6393 & 5.1 \\
\hline 92 & 26388 & Ifi202b & 510 & 2481 & 4.9 \\
\hline 93 & 56429 & Dpt & 3685 & 17070 & 4.6 \\
\hline 94 & 117167 & Steap4 & 2496 & 11485 & 4.6 \\
\hline 95 & 15483 & Hsd11b1 & 914 & 4119 & 4.5 \\
\hline 96 & 53603 & Tslp & 510 & 2219 & 4.4 \\
\hline 97 & 13479 & Dpep1 & 3131 & 13405 & 4.3 \\
\hline 98 & 216616 & Efemp1 & 167 & 690 & 4.1 \\
\hline 99 & 71145 & Scara5 & 406 & 1623 & 4.0 \\
\hline 100 & 74175 & 2300002G24Rik & 385 & 1506 & 3.9 \\
\hline 101 & 103250 & D130043N08Rik & 652 & 2544 & 3.9 \\
\hline 102 & 66693 & 4631408O11Rik & 3760 & 14564 & 3.9 \\
\hline 103 & 67513 & 2610002J02Rik & 174 & 672 & 3.9 \\
\hline 104 & 14012 & Eva1 & 214 & 825 & 3.9 \\
\hline 105 & 50764 & Fbxo15 & 160 & 604 & 3.8 \\
\hline 106 & 77125 & 9230117N10Rik & 1406 & 5292 & 3.8 \\
\hline 107 & 11475 & Acta2 & 4731 & 17691 & 3.7 \\
\hline 108 & 227753 & Gsn & 4076 & 14926 & 3.7 \\
\hline 109 & 14219 & Ctgf & 8112 & 29621 & 3.7 \\
\hline 110 & 67458 & 1200007D18Rik & 1646 & 5996 & 3.6 \\
\hline 111 & 57349 & Cxcl7 & 487 & 1742 & 3.6 \\
\hline
\end{tabular}


Table II. Continued.

No. Entrez Gene symbol Signal intensity Fold change

gene ID $\overline{\text { day } 1^{\mathrm{a}} \text { day } 4^{\mathrm{b}}}$ day $4 /$ day 1

\begin{tabular}{|c|c|c|c|c|c|}
\hline 112 & 20308 & Ccl9 & 1067 & 3803 & 3.6 \\
\hline 113 & 68713 & Ifitm1 & 317 & 1127 & 3.6 \\
\hline 114 & 20363 & Sepp1 & 3182 & 11272 & 3.5 \\
\hline 115 & 14066 & F3 & 855 & 3002 & 3.5 \\
\hline 116 & 21817 & $\operatorname{Tgm} 2$ & 2773 & 9708 & 3.5 \\
\hline 117 & 20198 & S100a4 & 154 & 534 & 3.5 \\
\hline 118 & 12814 & Col11a1 & 306 & 1058 & 3.5 \\
\hline 119 & 18542 & Pcolce & 922 & 3176 & 3.4 \\
\hline 120 & 83691 & Crispld1 & 499 & 1688 & 3.4 \\
\hline 121 & 11657 & Alb1 & 207 & 682 & 3.3 \\
\hline 122 & 260409 & Cdc42ep3 & 724 & 2367 & 3.3 \\
\hline 123 & 22359 & Vldlr & 193 & 621 & 3.2 \\
\hline 124 & 211623 & Plac9 & 848 & 2702 & 3.2 \\
\hline 125 & 11468 & $\operatorname{Actg} 2$ & 174 & 552 & 3.2 \\
\hline 126 & 26900 & $\operatorname{Ddx} 3 y$ & 434 & 1348 & 3.1 \\
\hline 127 & 269831 & Tspan12 & 353 & 1094 & 3.1 \\
\hline 128 & 68195 & Rnaset2 & 1541 & 4726 & 3.1 \\
\hline 129 & 18596 & Pdgfrb & 692 & 2084 & 3.0 \\
\hline 130 & 231507 & Plac8 & 2334 & 6984 & 3.0 \\
\hline 131 & 17190 & Mbd1 & 318 & 949 & 3.0 \\
\hline 132 & 16010 & Igfbp4 & 837 & 2454 & 2.9 \\
\hline 133 & 20750 & Spp1 & 1646 & 4824 & 2.9 \\
\hline 134 & 16525 & Kcnk1 & 217 & 626 & 2.9 \\
\hline 135 & 140742 & Sesn 1 & 876 & 2500 & 2.9 \\
\hline 136 & 14062 & $\mathrm{~F} 2 \mathrm{r}$ & 2695 & 7679 & 2.8 \\
\hline 137 & 193385 & 6330500D04Rik & 548 & 1553 & 2.8 \\
\hline 138 & 24010 & $\mathrm{Ik}$ & 3079 & 8670 & 2.8 \\
\hline 139 & 18741 & Pitx2 & 825 & 2303 & 2.8 \\
\hline 140 & 16819 & $\operatorname{Lcn} 2$ & 820 & 2287 & 2.8 \\
\hline 141 & 20315 & Cxcl12 & 2221 & 6181 & 2.8 \\
\hline 142 & 101351 & A130022J15Rik & 341 & 947 & 2.8 \\
\hline 143 & 11746 & Anxa4 & 3609 & 9800 & 2.7 \\
\hline 144 & 75746 & Morc4 & 615 & 1647 & 2.7 \\
\hline 145 & 226778 & Mark1 & 280 & 749 & 2.7 \\
\hline 146 & 231238 & 2310045A20Rik & 376 & 1006 & 2.7 \\
\hline 147 & 74055 & Plce1 & 584 & 1561 & 2.7 \\
\hline 148 & 67454 & 1200009F10Rik & 947 & 2505 & 2.6 \\
\hline 149 & 18805 & Pld1 & 277 & 727 & 2.6 \\
\hline 150 & 15228 & Foxg1 & 4190 & 10956 & 2.6 \\
\hline 151 & 23876 & Fbln5 & 744 & 1943 & 2.6 \\
\hline 152 & 70717 & 6330406I15Rik & 1104 & 2806 & 2.5 \\
\hline 153 & 67041 & Oxct1 & 1054 & 2650 & 2.5 \\
\hline 154 & 11522 & Adh1 & 8275 & 20776 & 2.5 \\
\hline 155 & 12834 & Col6a2 & 5465 & 13680 & 2.5 \\
\hline 156 & 110460 & Acat2 & 3936 & 9827 & 2.5 \\
\hline 157 & 64058 & Perp & 2013 & 4989 & 2.5 \\
\hline 158 & 231207 & Cpeb2 & 505 & 1241 & 2.5 \\
\hline 159 & 11982 & Atp10a & 514 & 1262 & 2.5 \\
\hline 160 & 192216 & Tm4sf10 & 2236 & 5452 & 2.4 \\
\hline 161 & 66214 & 1190002H23Rik & 377 & 919 & 2.4 \\
\hline 162 & 226251 & Ablim1 & 370 & 900 & 2.4 \\
\hline 163 & 12156 & Bmp2 & 208 & 504 & 2.4 \\
\hline 164 & 109552 & Sri & 218 & 527 & 2.4 \\
\hline 165 & 58809 & Rnase4 & 1802 & 4357 & 2.4 \\
\hline 166 & 106264 & 0610012G03Rik & 229 & 553 & 2.4 \\
\hline 167 & 16885 & Limk1 & 401 & 964 & 2.4 \\
\hline
\end{tabular}

Table II. Continued.

No. Entrez Gene symbol Signal intensity Fold change

\begin{tabular}{|c|c|c|c|c|}
\hline \multirow{2}{*}{\multicolumn{2}{|c|}{ gene ID }} & & \multirow[b]{2}{*}{ day 4/day 1} \\
\hline & & day $1^{\mathrm{a}}$ & day $4^{b}$ & \\
\hline 168 & 13506 Dsc2 & 1119 & 2683 & 2.4 \\
\hline 169 & 65255 Asb4 & 236 & 564 & 2.4 \\
\hline 170 & 19012 Рpap2a & 1704 & 4057 & 2.4 \\
\hline 171 & 66373 Lsm5 & 1856 & 4373 & 2.4 \\
\hline 172 & 55990 Fmo2 & 445 & 1048 & 2.4 \\
\hline
\end{tabular}

$55990 \mathrm{Fmo} 2$

17316952 Anxa1

17412369 Casp7

17519075 Prim1

176381066 BC049807

17758801 Pmaip1

17814560 Gdf10

$17912974 \mathrm{Cs}$

18067830 Rer1

18121826 Thbs 2

18267951 Tubb6

183100198 H6pd

18456744 Cxcl4

$\begin{array}{lll}12651 & 29731 & 2.4\end{array}$

$\begin{array}{llllll}185 & 66508 & 2400001 E 08 R i k & 2399 & 5455 & 2.3\end{array}$

$\begin{array}{lllll}186 & 320712 & \text { D930038M13Rik } 268 & 607 & 2.3\end{array}$

$\begin{array}{llllll}187 & 16987 & \text { Lss } & 321 & 726 & 2.3\end{array}$

18817110 Lzp-s $\quad 1065 \quad 2395 \quad 2.2$

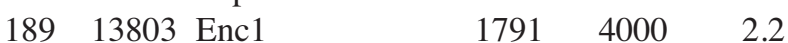

$\begin{array}{llllll}190 & 14701 \text { Gng12 } & 2388 & 5331 & 2.2\end{array}$

$\begin{array}{llllll}191 & 14137 & \text { Fdft1 } & 1385 & 3087 & 2.2\end{array}$

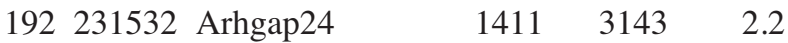

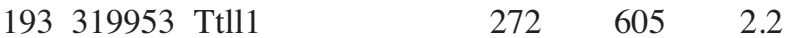

$\begin{array}{llllll}194 & 21898 & \text { Tlr4 } & 984 & 2185 & 2.2\end{array}$

$\begin{array}{llllll}195 & 19288 & \text { Ptx3 } & 5650 & 12541 & 2.2\end{array}$

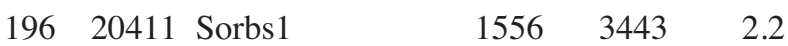

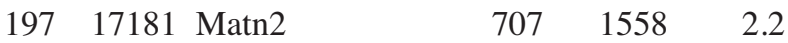

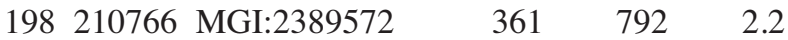

$\begin{array}{llllll}199 & 20393 & \text { Sgk } & 8914 & 19571 & 2.2\end{array}$

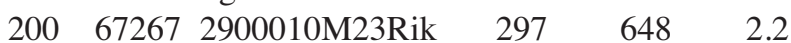

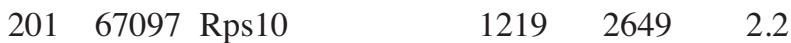

20250770 Atp11a $\quad 1011 \quad 2193 \quad 2.2$

$\begin{array}{lllll}203 & 13178 \text { Dck } & 526 & 1137 & 2.2\end{array}$

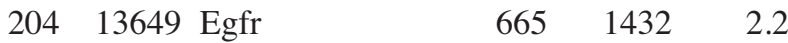

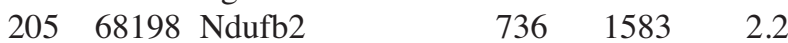

$\begin{array}{lllll}206 & 14873 \text { Gsto1 } & 4587 & 9817 & 2.1\end{array}$

$\begin{array}{llllll}207 & 13429 & \text { Dnm1 } & 534 & 1139 & 2.1\end{array}$

$\begin{array}{lllll}208 & 14866 \text { Gstm5 } & 379 & 806 & 2.1\end{array}$

$\begin{array}{llllll}209 & 76933 & \text { Ifi27 } & 380 & 808 & 2.1\end{array}$

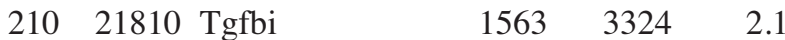

21122183 U2af1-rs1 $\quad 611 \quad 1293 \quad 2.1$

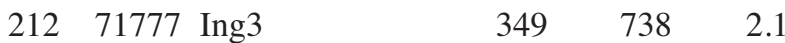

$\begin{array}{lllll}213 & 110454 \text { Ly6a } & 2931 & 6181 & 2.1\end{array}$

$\begin{array}{llllll}214 & 11796 & \text { Birc3 } & 3755 & 7918 & 2.1\end{array}$

$\begin{array}{llllll}215 & 74617 & \text { Scpep1 } & 4490 & 9460 & 2.1\end{array}$

21670316 Ndufab1 $\quad 2131 \quad 4488 \quad 2.1$

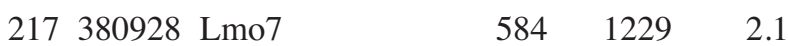

$\begin{array}{llllll}218 & 17750 & \text { Mt2 } & 11888 & 24924 & 2.1\end{array}$

$\begin{array}{llllll}219 & 192232 & \text { Hps4 } & 271 & 568 & 2.1\end{array}$

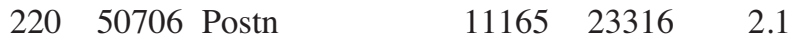

$\begin{array}{llllll}221 & 75751 & \text { Ipo4 } & 428 & 890 & 2.1\end{array}$

$\begin{array}{llllll}222 & 50887 & \text { Nsbp1 } & 1559 & 3243 & 2.1\end{array}$

$\begin{array}{lllll}223 & 16948 \text { Lox } & 21373 & 44425 & 2.1\end{array}$ 
Table II. Continued.

\begin{tabular}{|c|c|c|c|c|c|}
\hline \multirow[t]{2}{*}{ No. } & \multirow{2}{*}{$\begin{array}{l}\text { Entrez } \\
\text { gene ID }\end{array}$} & \multirow[t]{2}{*}{ Gene symbol } & \multicolumn{2}{|c|}{ Signal intensity } & \multirow{2}{*}{$\begin{array}{l}\text { Fold change } \\
\text { day } 4 / \text { day } 1\end{array}$} \\
\hline & & & day $1^{a}$ & day $4^{\mathrm{b}}$ & \\
\hline 224 & 12393 & Runx2 & 1313 & 2727 & 2.1 \\
\hline 225 & 75619 & 2810421I24Rik & 977 & 2025 & 2.1 \\
\hline 226 & 14605 & $\mathrm{Tsc} 22 \mathrm{~d} 3$ & 1272 & 2632 & 2.1 \\
\hline 227 & 12494 & $\mathrm{Cd} 38$ & 736 & 1522 & 2.1 \\
\hline 228 & 214384 & Myocd & 387 & 801 & 2.1 \\
\hline 229 & 70717 & 6330406I15Rik & 429 & 886 & 2.1 \\
\hline 230 & 14758 & Gpm6b & 5045 & 10427 & 2.1 \\
\hline 231 & 494504 & Apcdd1 & 360 & 744 & 2.1 \\
\hline 232 & 13056 & Cyb561 & 705 & 1456 & 2.1 \\
\hline 233 & 67005 & Polr3k & 1715 & 3533 & 2.1 \\
\hline 234 & 13602 & Sparcl1 & 248 & 510 & 2.1 \\
\hline 235 & 18032 & Nfix & 795 & 1632 & 2.1 \\
\hline 236 & 53614 & Reck & 2918 & 5990 & 2.1 \\
\hline 237 & 11745 & Anxa3 & 7875 & 16160 & 2.1 \\
\hline 238 & 101476 & Plekha1 & 2092 & 4287 & 2.0 \\
\hline 239 & 70536 & Qpct & 905 & 1852 & 2.0 \\
\hline 240 & 66152 & 1110020P15Rik & 252 & 515 & 2.0 \\
\hline 241 & 192216 & Tmem47 & 779 & 1587 & 2.0 \\
\hline 242 & 12825 & Col3al & 2757 & 5618 & 2.0 \\
\hline 243 & 17448 & Mdh2 & 1510 & 3076 & 2.0 \\
\hline 244 & 17846 & Commd1 & 703 & 1430 & 2.0 \\
\hline 245 & 59005 & 1810017G16Rik & 505 & 1027 & 2.0 \\
\hline 246 & 11504 & Adamts 1 & 6682 & 13595 & 2.0 \\
\hline 247 & 57342 & Parva & 406 & 825 & 2.0 \\
\hline 248 & 11842 & Arf3 & 1695 & 3427 & 2.0 \\
\hline 249 & 12235 & Bub1 & 940 & 1897 & 2.0 \\
\hline 250 & 16007 & Cyr61 & 601 & 1212 & 2.0 \\
\hline 251 & 67217 & 2810055F11Rik & 256 & 517 & 2.0 \\
\hline 252 & 15122 & Hba-a1 & 1256 & 2524 & 2.0 \\
\hline 253 & 51869 & Rif1 & 364 & 732 & 2.0 \\
\hline 254 & 16009 & Igfbp3 & 1964 & 3944 & 2.0 \\
\hline 255 & 211739 & BC027127 & 529 & 1060 & 2.0 \\
\hline 256 & 22004 & Tpm2 & 6920 & 13819 & 2.0 \\
\hline 257 & 11489 & Adam12 & 1700 & 3394 & 2.0 \\
\hline 258 & 15959 & Ifit3 & 1114 & 2219 & 2.0 \\
\hline 259 & 353208 & 2810021G02Rik & 784 & 1555 & 2.0 \\
\hline 260 & 69706 & Ppil5 & 655 & 1299 & 2.0 \\
\hline 261 & 18783 & Pla2g4a & 4337 & 8596 & 2.0 \\
\hline 262 & 12702 & Socs 3 & 998 & 1977 & 2.0 \\
\hline 263 & 17748 & Mt1 & 35272 & 69789 & 2.0 \\
\hline 264 & 67204 & Eif2s2 & 5698 & 11262 & 2.0 \\
\hline 265 & 19366 & Rad541 & 254 & 502 & 2.0 \\
\hline 266 & 21412 & Tcf21 & 408 & 806 & 2.0 \\
\hline 267 & 15958 & Ifit2 & 1526 & 3011 & 2.0 \\
\hline 268 & 56309 & Mycbp & 267 & 527 & 2.0 \\
\hline 269 & 19242 & Ptn & 1268 & 2500 & 2.0 \\
\hline 270 & 14190 & Fgl2 & 444 & 874 & 2.0 \\
\hline 271 & 19876 & Robo1 & 798 & 1572 & 2.0 \\
\hline 272 & 67732 & 4833421E05Rik & 513 & 1010 & 2.0 \\
\hline 273 & 11534 & Adk & 5483 & 10780 & 2.0 \\
\hline 274 & 67054 & Paics & 4279 & 8394 & 2.0 \\
\hline
\end{tabular}

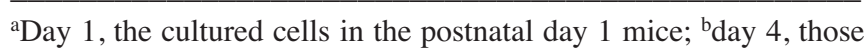
in the postnatal day 4 mice. ${ }^{\mathrm{c} I n}$ the signal intensity of day 1,1 means undetectable (absence). expressed in the esophageal epithelial cell primary culture of the postnatal day 4 mice compared with that of the postnatal day 1 mice. Since the primary cultured cells were prepared on day 2 of the primary culture, they primarily consisted of the basal cells described above. Therefore, it was expected that these three receptor genes would be highly expressed in the basal cells of the postnatal day 4 mice compared with that of the postnatal day 1 mice. For confirmation, we prepared RNA samples from two specimens: one (B) contained the basal cells, and the other (D+E) contained both the epibasal cells and the differentiated squamous cells by LCM (Fig. 5A). We then performed RT-PCR after amplification of a small amount of RNA (10-20 ng) by TALPAT (8). The mRNA of a basal cell marker gene Krt14 was detected preferentially in specimen $\mathrm{B}$, demonstrating that the target cells were effectively enriched by LCM. Both Pdgfrb and Egfr were expressed highly in specimen $\mathrm{B}$ of the postnatal day 4 mice compared with that of the postnatal day 1 mice (Fig. 5B). Thus, overexpression of $P d g f r b$ and Egfr is associated with the timing of accelerated growth of the esophageal epithelium in young mice.

\section{Discussion}

We discovered a unique phenomenon that the growth of the esophageal epithelium shows a remarkable activation point around postnatal day 3 in mice. In mammals, the neonate ingests breast milk very soon after birth, and then is infected orally with microorganisms through both lactation and other maternal care. This delayed start system may provide time for acquiring immunoresponsibility against microorganisms. Expressional and functional analyses of Toll-like receptors in young mice will be an interesting project in the future. To date, it is not known why growth is delayed and whether the same phenomenon occurs in humans. However, our finding provides a new experimental model for studies on self-renewal of esophageal epithelial stem cells.

Esophageal squamous cell carcinoma has a poor prognosis because of frequent metastasis to the lymph nodes and lungs (14-16). There is no radical therapy for patients with metastases. Studies on the molecular mechanisms of self-renewal of adult stem cells is quite important for understanding cancer cell growth and/or cancer stem cell growth. In the self-renewal of hematopoietic stem cells, the signaling of Wnt (17-20), Notch $(21-23)$, and HoxB4 $(24,25)$ is reported to be involved. In the neural stem or precursor cells, Bmil has been reported to have a critical role (26). Only the hedgehog signaling pathway has been involved in the self-renewal of a variety of organs including the brain $(27,28)$, lung $(29)$, pancreas $(30)$, bone (31), and skin (32). In the stomach, Shh and Dhh expression have been shown to be greatest at the pit-gland transition and restricted to the parietal cells $(33,34)$, while Ihh was expressed in the pit cells (34). Although the hedgehog signaling pathway acts as a polarizing signal for bi-directional differentiation in the stomach $(33,34)$, it remains unknown whether this pathway plays a role in maintaining stem or precursor cells, owing to the lack of an in vitro culture system for expansion of those cells. In the esophagus, hedgehog signal activation itself is unclear (35). Here we report that NGF signaling is a candidate for the self-renewal of the esophageal epithelial stem cell. 
A

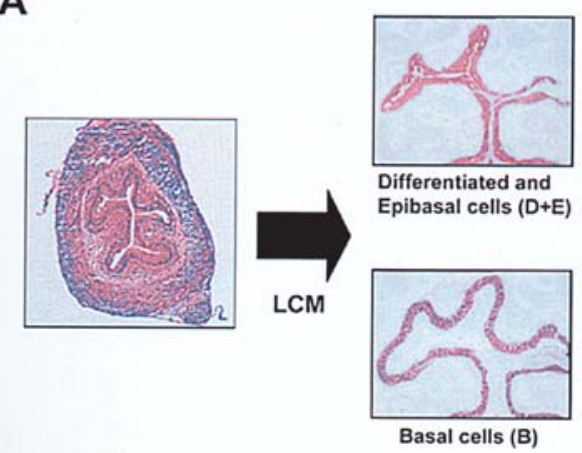

B

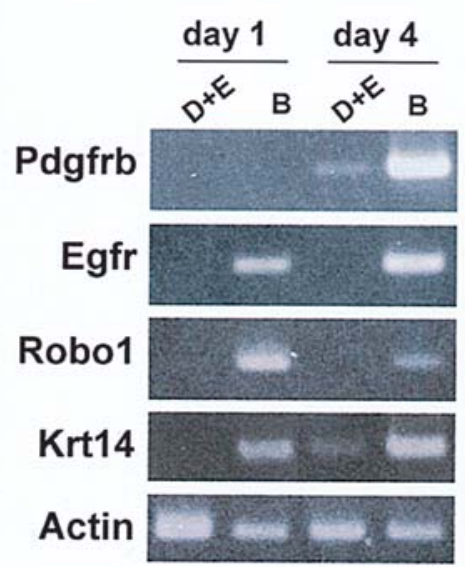

Figure 5. Expressional change of other receptor genes in the basal cell during growth. (A) Two different specimens, one (B) contained the basal cells, and the other $(D+E)$ contained both the differentiated squamous cells and the epibasal cells, were prepared by laser-captured microdessection. (B) RT-PCR of Robo1, Pdgfrb and Egfr in the RNA samples from the two specimens. Pdgfrb and Egfr mRNAs were expressed at a higher level in the specimen $B$ of postnatal day 4 mice than in that of the postnatal day 1 mice.

Consistent with the overexpression of Egfr and Pdgfrb in postnatal day 4 mice, Egf is known to be an essential growth factor for maintaining squamous cell cultures in the absence of serum, and Pdgf has also been reported to maintain the small side population, which is enriched for stem cells, in the C6 glioma cell line (2). These two growth factor receptor genes could be required for the basal cell self-renewal in the esophagus. Our extensive gene list and the present mouse primary culture system can contribute to studies on the selfrenewal of the basal cells and keratinocyte differentiation in the esophagus.

Expression analysis of receptor genes in laser-captured cells revealed that Robol and Egfr are expressed in the basal cells in the mouse neonates but not in those in adult mice (Fig. 5B). This suggests that the signal transduction through some receptors acts on the stem cells only in the growing stage. Therefore, in situ expression analysis by laser-captured basal cells is thought to be very important. Consistent with other reports (36-42), the TALPAT, which was used in RNA amplification of a very small amount of the laser-captured cells and the primary cultured cells (Fig. 5 and Table II), is thereby confirmed in its efficiency and high-fidelity. This method should be applied to the in situ expression analysis in the mouse neonates and adult mice in the future.

\section{Acknowledgments}

This work was supported in part by the program for promotion of Fundamental Studies in Health Sciences of the National Institute of Biomedical Innovation, in part by a Grant-in-Aid for the Third Comprehensive 10-Year Strategy for Cancer Control and for Cancer Research (16-15) from the Ministry of Health, Labour and Welfare of Japan, and in part by a research grant of the Princess Takamatsu Cancer Research Fund. H.D., N.I., and M.S. were awardees of research resident fellowships from the Foundation for Promotion of Cancer Research.

\section{References}

1. Al-Hajj M, Wicha MS, Benito-Hernandez A, Morrison SJ and Clarke MF: Prospective identification of tumorigenic breast cancer cell. Proc Natl Acad Sci USA 100: 3983-3988, 2003.

2. Kondo T, Setoguchi T and Taga T: Persistence of a small subpopulation of cancer stem-like cells in the C6 glioma cell line. Proc Natl Acad Sci USA 101: 781-786, 2004.

3. Singh SK, Hawkins C, Clarke ID, Squire JA, Bayanl J, Hide T, Henkelman RM, Cusimano MD and Dirks PB: Identification of human brain tumour initiating cells. Nature 432: 396-401, 2004.

4. Huntly BJP and Gilliland DG: Leukaemia stem cell and the evolution of cancer-stem-cell research. Nat Rev Cancer 5: 311-321, 2005.

5. Kim CFB, Jackson EL, Woolfender AE, Lawrence S, Badar I, Vogel S, Crowley D, Bronson RT and Jacks T: Identification of bronchioalveolar stem cells in normal lung and lung cancer. Cell 121: 823-835, 2005

6. Seery JP and Watt FM: Asymmetric stem-cell divisions define the architecture of human oesophageal epithelium. Curr Biol 10: 1447-1450, 2000.

7. Seery JP: Stem cell of the oesophageal epithelium. J Cell Science 115: 1783-1789, 2002.

8. Aoyagi K, Tatsuta T, Nishigaki M, Akimoto S, Tanabe C, Omoto Y, Hayashi S, Sakamoto H, Sakamoto M, Yoshida T, Terada M and Sasaki H: A faithful method for PCR-mediated global mRNA amplification and its integration into microarray analysis on laser-captured cells. Biochem Biophys Res Commun 300: 915-920, 2003.

9. Okumura T, Shimada Y, Imamura $\mathrm{M}$ and Yasumoto $\mathrm{S}$ : Neurotrophin receptor $\mathrm{p} 75^{\mathrm{NTR}}$ characterizes human esophageal keratinocyte stem cell in vitro. Oncogene 22: 4017-4026, 2003.

10. Dobson H, Pignatelli M, Hopwood D and D'Arrigo C: Cell adhesion molecules in oesophageal epithelium. Gut 35: 1343-1347, 1994

11. Barker PA, Miller FD, Large TH and Murphy RA: Generation of the truncated form of the nerve growth factor receptor by rat schwann cells. J Biol Chem 266: 19113-19119, 1991.

12. Squier CA and Kremer MJ: Biology of oral mucosa and esophagus. J Natl Cancer Inst Monogr 29: 7-15, 2001.

13. Banks-Schlegel S and Green H: Involucrin synthesis and tissue assembly by keratinocytes in natural and cultured human epithelia. J Cell Biol 90: 732-737, 1981.

14. Osugi H, Takemura M, Higashino M, Takada N, Lee S, Ueno M, Tanaka Y, Fukuhara K, Hashimoto Y, Fujiwara Y and Kinoshita H: Causes of death and pattern of recurrence after esophagectomy and extended lymphadenectomy for squamous cell carcinoma of the thoracic esophagus. Oncol Rep 10: 81-87, 2003.

15. Lee SJ, Lee KS, Yim YJ, Kim TS, Shim YM and Kim K: Recurrence of squamous cell carcinoma of the oesophagus after curative surgery: rates and patterns on imaging studies correlated with tumour location and pathological stage. Clinic Radiol 60: 547-554, 2005.

16. Motoyama S, Kitamura M, Saito R, Maruyama K, Okuyama M and Ogawa J: Outcome and treatment strategy for mid- and lower- thoracic esophageal cancer recurring locally in the lymph nodes of the neck. World J Surg 30: 191-198, 2006.

17. Reya T, Duncan AW, Ailles L, Domen J, Scherer DC, Willert K, Hintz L, Nusse R and Weissman IL: A role for Wnt signaling in self-renewal of haematopoietic stem cells. Nature 423: 409-414, 2003. 
18. Muller-Tidow C, Steffen B, Cauvet T, Tickenbrock L, Ji P, Diederichs S, Sargin B, Kohler G, Stelljes M, Puccetti E, Ruthardt M, deVos S, Hiebert SW, Koeffler HP, Berdel WE and Serve H: Translocation products in acute myeloid leukemia activate the Wnt signaling pathway in hematopoietic cells. Mol Cell Biol 24: 2890-2904, 2004.

19. Zheng X, Beissert T, Kukoc-Zivojnov N, Puccetti E, Altshmied J, Strolz C, Boehrer S, Gul H, Schneider O, Ottmann OG, Hoelzer D, Henschler R and Ruthardt M: Gamma-catenin contributes to leukemogenesis induced by AML-associated translocation products by increasing the self-renewal of very primitive progenitor cells. Blood 103: 3535-3543, 2004.

20. Reya T and Clevers H: Wnt signaling in stem cells and cancer. Nature 434: 843-850, 2005.

21. Duncan AW, Rattis FM, DiMascio LN, Congdon KL, Pazianos G, Zhao C, Yoon K, Cook JM, Willert K, Gaiano N and Reya T: Integration of Notch and Wnt signaling in hematopoietic stem cell. Nat Immunol 6: 314-322, 2005.

22. Varnum-Finney B, Xu L, Brashem-Stein C, Nourigat C, Flowers D, Bakkour S, Pear WS and Bernstein ID: Pluripotent, cytokine-dependent, hematopoietic stem cells are immortalized by constitutive Notch1 signaling. Nat Med 6: 1278-1281, 2000.

23. Karanu FN, Murdoch B, Gallacher L, Wu DM, Koremoto M, Sakano $\mathrm{S}$ and Bhatia M: The notch ligand jagged-1 represents a novel growth factor of human hematopoietic stem cells. J Exp Med 192: 1365-1372, 2000.

24. Sauvageau G, Thorsteinsdottir U, Eaves CJ, Lawrence HJ, Largman C, Lansdorp PM and Humphries RK: Over expression of HOXB4 in hematopoietic cells causes the selective expansion of more primitive populations in vitro and in vivo. Genes Dev 9: 1753-1765, 1995.

25. Antonchuk J, Sauvageau G and Humphries RK: HOXB4induced expansion of adult hematopoietic stem cells ex vivo. Cell 109: 39-45, 2002.

26. Valk-Lingbeek ME, Bruggeman SW and van Lohuizen M: Stem cells and cancer; the polycomb connection. Cell 118: 409-418, 2004.

27. Wechsler-Reya RJ and Scott MP: Control of neuronal precursor proliferation in the cerebellum by Sonic Hedgehog. Neuron 22: 103-114, 1999.

28. Palma V, Lim DA, Dahmane N, Sanchez P, Brionne TC, Herzberg CD, Gitton Y, Carleton A, Alvarez-Buylla A, Ruiz I and Altaba A: Sonic hedgehog controls stem cell behavior in the postnatal and adult brain. Development 132: 335-344, 2005.

29. Watkins DN, Berman DM, Burkholder SG, Wang B, Beachy PA and Baylin SB: Hedgehog signaling within airway epithelial progenitors and in small-cell lung cancer. Nature 422: 313-317, 2003.

30. Kawahira H, Scheel DW, Smith SB, German MS and Hebrok M: Hedgehog signaling regulates expansion of pancreatic epithelial cells. Dev Biol 280: 111-121, 2005.

31. Wdwards PC, Ruggiero S, Fantasia J, Burakoff R, Moorji SM, Paric E, Razzano P, Grande DA and Mason JM: Sonic hedgehog gene-enhanced tissue engineering for bone regeneration. Gene Ther 12: 75-86, 2005.
32. Adolphe C, Narang M, Ellis T, Wicking C, Kaur P and Wainwright $\mathrm{B}$ : An in vivo comparative study of sonic, desert and Indian hedgehog reveals that hedgehog pathway activity regulates epidermal stem cell homeostasis. Development 131: 5009-5019, 2004.

33. Van den Brink GR, Hardwick JC, Tytgat GN, Brink MA, Ten Kate FJ, Van Deventer SJ and Peppelenbosch MP: Sonic hedgehog regulates gastric gland morphogenesis in man and mouse. Gastroenterology 121: 317-328, 2001.

34. Fukaya M, Isohata N, Ohta H, Aoyagi K, Ochiya T, Saeki N, Yanagihara K, Nakanishi Y, Taniguchi H, Sakamoto H, Shimoda T, Nimura Y, Yoshida T and Sasaki H: Hedgehog signal activation in gastric pit cell and diffuse type gastric cancer. Gastroenterology 131: 14-29, 2006.

35. Lees C, Howie S, Sartor RB and Satsangi J: The hedgehog signaling pathway in the gastrointestinal tract: implications for development, homeostasis, and disease. Gastroenterology 129: 1696-1710, 2005.

36. Mori K, Aoyagi K, Ueda T, Danjoh I, Tsubosa Y, Yanagihara K, Matsuno Y, Sasako M, Sakamoto H, Mafune K, Kaminishi M, Yoshida T, Terada M and Sasaki H: Highly specific marker genes for detecting minimal gastric cancer cells in cytology negative peritoneal washings. Biochem Biophys Res Commun 313: 931-937, 2004.

37. Kobayashi K, Nishioka M, Kohno T, Nakamoto M, Maeshima A, Aoyagi K, Sasaki H, Takenoshita S, Sugimura H and Yokota J: Identification of genes whose expression is upregulated in lung adenocarcinoma cells in comparison with type II alveolar cells and bronchiolar epithelial cells in vivo. Oncogene 23: 3089-3096, 2004.

38. Nishigaki M, Aoyagi K, Donjoh I, Fukaya M, Yanagihara K, Sakamoto H, Yoshida T and Sasaki H: Discovery of aberrant expression of R-RAS by cancer-linked DNA hypomethylation in gastric cancer using microarrays. Cancer Res 65: 2115-2124, 2005.

39. Tatsuta T, Mukaisho K-I, Sugihara H, Miwa K, Tani T and Hattori T: Expression of Cdx2 in early GRCL of barrett's esophagus induced in rats by duodenal reflux. Dig Dis Sci 50: 425-431, 2005.

40. Yamada K, Kano J, Tsunoda H, Yoshikawa H, Okubo C, Ishiyama $\mathrm{T}$ and Noguchi $\mathrm{M}$ : Phenotypic characterization of endometrial stromal sarcoma of the uterus. Cancer Sci 97: 106-112, 2006.

41. Nakamura N, Kobayashi K, Nakamoto M, Kohno T, Sasaki H, Matsuno Y and Yokota J: Identification of tumor markers and differentiation markers for molecular diagnosis of lung adenocarcinoma. Oncogene (in press).

42. Nygaard V and Hovig E: Options available for profiling small samples: a review of sample amplification technology when combined with microarray profiling. Nucleic Acids Res 34: 996-1014, 2006. 